\title{
Religijska imaginacija i suvremena javna teologija
}

\section{Beneamin Mocan}

Faculty of Humanities and Social Sciences of the 'Aurel Vlaicu' University of Arad, Romania beni.mocan@yahoo.com

UDK: 141.78:316.42(498):27-1 Pregledni rad https://doi.org/10.32862/k1.15.1.7

\section{Sažetak}

Proces sekularizacije, poznat $i$ kao proces privatizacije religije, odnosno njezino uklanjanje iz javnog $i$ društvenog života, predstavlja baštinu modernizma. Ova je realnost u značajnoj mjeri utjecala (i još uvijek utječe) na kršćansku teologiju. Zbog toga postoji hitna i značajna potreba za obnovom kršćanske teologije, posebno kad je riječ o potrebi za obnovljenom kršćanskom porukom u suvremenom društvu. Premda se činilo kako je javna teologija normalna posljedica potrebe za obnovom kršćanske teologije, ne znači da je obnova zapravo prisutna u mnogim njezinim metodama. Nefleksibilnost njezinih teoloških metoda i terminologije i dalje predstavljaju problem za javnu teologiju. U ovom članku sugeriramo da, pri konstruiranju održive javne teologije, valja uvažiti ovaj novi pomak u antropologiji. Kategorija "religijske imaginacije" od vitalnog je značaja jer uvažava novu definiciju ljudskog bića koja je bliža postmodernizmu nego modernizmu. Zato u članku prikazujemo mogući značajan doprinos koji religijska imaginacija može pružiti u svrhu revitalizacije suvremene javne teologije. Nadalje, u članku spominjemo nedavna rumunjska istraživanja o ovoj temi u kojima se stavlja još veći naglasak na bogatstvo skriveno u njemu i njezinu moguću svrhu u konstruiranju održive javne teologije.

Ključne riječi: socijalna i religijska imaginacija, javna teologija, globalizacija, nova antropologija, modernizam, postmodernizam 


\section{Uvod}

Ne smijemo i ne možemo zanijekati realnost globalizacije i novoga javnog prostora jer u velikoj mjeri utječu na cjelokupnu globalnu i lokalnu egzistenciju ljudi. Tehnološki i znanstveni napredak iz proteklih desetljeća doprinio je - a i dalje itekako doprinosi - rođenju i održavanju globalne realnosti, što nosi ozbiljne implikacije ne samo za politički, društveni i kulturni život ljudi nego i za njihov religijski život te za njihovo poimanje religije i vjerovanja, kao i za njihovu svrhovitost u eri globalizacije. Ima li kršćanska vjera i dalje čime doprinijeti i što ponuditi ovako kompleksnom društvu, koje često definira samo sebe kao ateističko, pa čak i antiteističko? Treba li ili ne treba uzeti u obzir ove velike promjene u suvremenom društvu? Ako treba, koje to realnosti kršćanska teologija treba uzeti u obzir i zašto? Treba li uskladiti svoj teološki diskurs sa sadašnjošću ili se može nastaviti služiti istim diskursom zbog toga što njezina istinitost nadilazi svakodnevne realnosti te je relevantna za njih, neovisno o promjenama koje se odvijaju u društvu?

U ovome članku nastojat ćemo dati kratke odgovore na ova i njima slična pitanja. Stoga, započet ćemo svoj pristup afirmacijom realiteta globalizacije i transformacija, što ih je ovaj fenomen izazvao u ljudskom društvu. Nastavit ćemo razlučivanjem nove antropologije i potrebom za obnovom suvremenoga teološkog diskursa. Tako ćemo pokazati kako se „javna teologija“ rađa iz potrebe za obnovom kršćanske teologije; međutim, ipak ostaje čvrsto usidrena u metodama konvencionalne teologije i smatramo da ne uspijeva na zadovoljavajući način odgovoriti na potrebe suvremenog čovjeka i društva. Zato predlažemo poimanje kršćanske teologije i religijske tradicije kao „imaginarne“, što je kategorija do koje smo došli uz pomoć lokalnih rumunjskih mislilaca.

\section{Realnost globalizacije}

U IV. svesku svoje studije God and Globalization, Max Stackhouse $(2007,1)$ smatra da je fenomen globalizacije najvažniji izazov koji se nalazi pred cjelokupnim čovječanstvom budući da je „kompleksna dinamika globalizacije“ dovela do nastanka „novog, proširenijeg javnog prostora“, što ima značajne posljedice za cjelokupnu kršćansku vjeru. Os Guinness i David Wells $(2010,1)$ u zajedničkom članku još ističu značaj fenomena globalizacije za razumijevanje kršćanske vjere i kršćanske teologije, ističući kako vizija „cjelovitog Evanđelja za cijeli svijet posredstvom cjelokupne Crkve“ nikad nije bila stvarnija, ali ni žešće propitkivanja. Njihovo opažanje smatramo iznimno relevantnim budući da je kršćanska Crkva općenito, a konkretno kršćanska teologija, osobito nespremna s punom odgovornošću i zainteresiranošću pozabaviti se realitetom globalizacije i važnih civilizacijskih i epistemoloških promjena do kojih je dovela. Razumljivo donošenje ili navješćivanje Evanđelja iziskuje temeljito znanje o realnostima suvremenog 
društva, a Guinness i Wells su toga svjesni. Nadalje, oni uz to definiraju globalizaciju kao „višedimenzijski proces u kojem odlučujući čimbenik za njezino sadašnje širenje nije kapitalizam, nego tehnologija" (Guinness i Wells 2010, 2).

Budući da fenomen tehnologije predstavlja okosnicu globalizacije i da utječe na većinu, ako ne i sve, aspekte ljudskog života, Guinness i Wells $(2010,2)$ govore o tri velika koraka koja kršćanska teologija mora razmotriti kad je riječ o fenomenu globalizacije: (1) razlučivanju i razumijevanju kompleksnih društvenih realnosti, (2) pomnom procjenjivanju dobrih i loših strana globalizacije, (3) društvenom angažmanu temeljenom na toj poziciji. Takav pristup fenomenu globalizacije odgovoran je, a u isti mah je smion, jer ne uzmiče pred kompleksnošću problema što ih ona donosi, kao ni pred njihovom brojnošću.

Stackhouse $(2007,8)$ ide korak dalje i postavlja globalizaciju kao središnje pitanje za kršćansku teologiju:

[G]lobalizaciju ćemo najbolje shvatiti kao globalni sustav društvene, političke, kulturne, tehnološke i etičke dinamike na koju su utjecali i kojem su legitimnost pružili određeni teološki, etični i ideološki motivi koji stvaraju globalno građansko društvo koje nadilazi kapacitete bilo koje nacionalne države. Taj sustav utječe na sve lokalne kontekste, sve narode, sve društvene ustanove, kao i na ekologiju same Zemlje. On formira alternativni postmodernizam koji sadrži elemente fragmentacije i relativizacije svih prethodnih sigurnosti, ali i to iziskuje ponovno otkrivanje univerzalističkih načela antropologije, duhovnosti, moralnosti i zakona, čime se diferenciraju razni ciljevi i formiraju se nove ustanove koje iziskuju sveopće priznanje. Tako nastaje nova javnost koja argumentira i promišlja, koja modulira svaki regionalni i lokalni kontekst, ali im se prilagođava i prihvaćena je u njima na neki novi način. Utoliko on ruši stare prepreke među ljudima i stvara nove načine tumačenja i definiranja identiteta, usmjeravajući svijet u neočekivanim smjerovima. ${ }^{1}$

Lako je uočiti da je prva veća promjena koju Stackhouse spominje ona antropološka. Ako gledamo na globalizaciju samo kao na puki izričaj nove antropologije, tj. kao na novu definiciju ljudskih bića, to nosi velike implikacije za kršćansku teologiju. Drugim riječima, globalizacija otkriva debatu oko definiranja

1 "[G]lobalization is best understood as a worldwide set of social, political, cultural, technological and ethical dynamics, influenced and legitimated by certain theological, ethical and ideological motifs, that are creating a worldwide civil society that stands beyond the capacity of any nationstate to control. It is influencing every local context, all peoples, all social institutions and the ecology of the earth itself. It is forming an alternative postmodernism, one that has elements of the fragmentation and the relativization of all previous securities, but that also is demanding the rediscovery of the universalistic principles of anthropology, spirituality, morality and law, refining distinctive purposes and forming new institutions that require common recognition. Thereby it is creating a newly contentious, comprehending public, one that modulates every regional and local context and yet is adapted into them and adopted by them in novel ways. In that way, it breaks down old barriers between people and creates new ways of interpreting and defining identities as it converts the world in unexpected directions." 
ljudskih bića između modernizma i postmodernizma, što nosi velike implikacije za naš današnji pristup teologiji.

\section{Antropološka revolucija}

Antropologiju modernizma vrlo dobro objašnjava teolog James K. A. Smith, služeći se sugestivnim izrazom, govoreći o čovjeku kao o „stroju koji smišlja misli“ (Smith 2010, 56). Govorimo, dakle, o redukcionističkoj antropologiji modernizma, gdje se na čovjeka gleda kroz prizmu „obestrašćenog objektivizma“ (Smith 2010, 59). Za modernizam, njegov političko-gospodarski projekt predstavljao je najmanji prioritet, što znači da su ljudska bića od sekundarnog značaja. Stoga, on je bio prisiljen narušiti integritet ljudskog bića i svesti ga na „stroj koji misli“, koji nadalje može iskoristiti u ostvarivanju svojih ciljeva.

S druge strane, postmodernistička antropologija predstavlja grubi kontrast modernističkoj antropologiji, upućujući joj oštre kritike. Stoga, ljude se shvaća u holističkom smislu, a ne kao bića koja su svedena isključivo na svoju sposobnost razmišljanja. David Brooks, američki javni intelektualac, pruža izvrsnu ilustraciju ove realnosti. U svojoj knjizi The Social Animal Brooks govori o „unutarnjem umu" i o njegovu značaju u novoj antropologiji. Pod unutarnjim umom Brooks misli na sferu ljudskog nesvjesnoga, odnosno na „emocije, intuicije, predrasude, strasti, genetske predispozicije, karakterne osobine i društvene norme" (Brooks 2011, x). Brooks donosi priču o Haroldu i Eriki, likovima iz knjige, kako bi ilustrirao određenu postmodernističku antropologiju: onu koja pomno razmatra antropološku revoluciju postmodernizma budući da je čvrsto uvjeren kako se čovječanstvo „nalazi usred revolucije ljudske svjesnosti“ (Brooks 2011, x). On gradi na otkrićima znanstvenika koji, u svojim nastojanjima da dešifriraju proces po kojem suvremeno društvo može postići autentični procvat čovjeka, tvrde da je ključ za ostvarivanje ovog cilja u razumijevanju činjenice da ljudi „nisu u prvom redu proizvod svjesnog razmišljanja“, nego da su „primarno rezultat razmišljanja koje se odvija ispod razine svjesnosti“ (Brooks 2011, x).

Timothy Wilson $(2002,5)$ ide u istom smjeru kad kaže da se stvari koje znamo o sebi „ne mogu izravno spoznati“, čak ni uz pomoć najdetaljnije introspekcije, i još napominje da živimo u vremenu kad već postoji čvrsta znanstvena osnova za „značaj podsvjesnog razmišljanja, osjećaja i motivacija“. To ne znači da razum nije važan dio ljudske antropologije. Radije, govorimo o promjeni paradigme iz racionalizirane redukcionističke ljudske antropologije $u$ afektivnu ljudsku antropologiju, koja uokviruje holističko ljudsko biće, gdje se pretpostavlja da su njegove sklonosti organski dio cjeline, odnosno da se radi o cjelokupnoj kompleksnosti „unutarnjeg uma“ o kojem smo ranije govorili. Wilson $(2002,54)$ stoga može tvrditi da je „vrlo moguće da ono podsvjesno snažnije utječe na naše ponašanje“ nego ono svjesno. 
Kod Brooksa (2011, xi) je još fascinantnije to što uvrštava ljudske osjećaje u sferu podsvjesnoga, opisujući ih kao mjesto gdje se događaju značajni procesi, gdje nije u pitanju „napušteno, mehaničko mjesto“, nego „emocionalno, začarano područje“. Ako je modernistička antropologija naglašavala središnju ulogu razuma, postmodernistička antropologija naglašava središnjost ljudskih osjećaja, emocija i strasti. Ipak, u ovoj fazi našeg pristupa trebamo se osvrnuti na izvjesnu Brooksovu (2011, xi) opasku: „Ako izvanjski um ističe moć pojedinca, unutarnji um ističe moć međuljudskih odnosa i nevidljivih veza među ljudima. Ako izvanjski um žudi za statusom, novcem i aplauzom, unutarnji um žudi za skladom i povezanošću - to su oni trenuci gdje svijest o sebi blijedi i osoba se gubi u izazovu, cilju, ljubavi druge osobe ili ljubavi prema Bogu“.

Ne smijemo se fokusirati na način na koji se Brooks služi antitezama „izvanjski um“ $i$, unutarnji um“ jer bismo tako previdjeli središnji element njegove opaske. Razumijevajući čovjeka u postmodernističkom smislu, on spašava ljudsku antropologiju od modernističkog redukcionizma koji se na nju primjenjuje. Ovo je središnji element postmodernističke antropologije: čovjek je više od razuma te ga se ne može svesti samo na razum. Uz to, društvo i stvorenje čovjeka nisu izopačeni, nego su, poput njihova stvoritelja, začarano područje koje se ne može objasniti isključivo racionalno.

\section{Javna teologija: obnova kršćanske teologije?}

Javna teologija stupa na globalnu pozornicu s velikim potencijalom. To se uglavnom može zaključiti iz načina na koji je definiramo. Jednu od najpoznatijih definicija ponudio je Duncan Forrester $(2004,6)$. Javna teologija je „teologija koja traži dobrobit grada prije zaštite interesa Crkve ili njezina prava da propovijeda evanđelje i proslavlja sakramente“. Javna teologija, dakle, ima za cilj pozabaviti se najakutnijim sociokulturnim problemima suvremenog društva. Njezina je glavna svrha, stoga, pohvalna. I zato, da bi ispunila svoju svrhu, javna teologija mora, kao što smo već rekli, razmotriti promjenu paradigme u ljudskoj antropologiji.

Nadalje, Forrester $(2004,6)$ ističe da se javna teologija služi riznicom određene religijske tradicije „kako bi doprinijela izgradnji poštenog društva, obuzdavanju zla, suzbijanju nasilja, izgradnji zemlje i izmirenju u javnom prostoru“. Tako, javna teologija ne samo što ima preciznu svrhu - usvojiti program društva, nego ima i jasan temelj: riznicu određene religijske tradicije. Svaka javna teologija temelji se na toj riznici vjere. $S$ druge strane, u ovom je trenutku ključno naglasiti da, kao što na svrhu javne teologije treba gledati kroz prizmu nove antropologije ljudi, tako se i na temelj javne teologije treba gledati kroz istu hermeneutičku prizmu. Drugim riječima, bilo koju vjersku tradiciju treba razumjeti iz perspektive promjena u paradigmi nove antropologije koju smo ranije opisivali. 
Čak i kad bi se javna teologija pojavila na globalnoj pozornici, obećavajući obnovu teološkog diskursa i, shodno tomu, transformaciju ljudskog društva u potrazi za općim dobrom i napretkom čovjeka, moramo istaknuti činjenicu da su mnogi njezini pristupi i metode i dalje duboko ukorijenjeni u starim redukcionističko-modernističkim antropološkim paradigmama. ${ }^{2}$

Ova je realnost normalna zbog toga što se javna teologija, prema našem mišljenju, nalazi u razdoblju tranzicije iz starih metodologija konvencionalne kršćanske teologije - onih iz prosvjetiteljstva - prema metodama koje odgovaraju paradigmatskoj promjeni o kojoj ovdje govorimo. Zato Stackhouse gleda na teologiju holistički, definirajući je iz perspektive nove antropologije: s naglaskom na materijalnost ljudskog postojanja, socijalnog pluralizma i pojma globalizacije, kao što smo već vidjeli u spomenutoj definiciji.

Međutim, Stackhouse $(1987,2)$ izjavljuje da nije potpuno zadovoljan metodama izgradnje javne teologije: „Ključni je problem u tome što nemamo dobro razrađenu javnu teologiju. [...] ono što nemamo jest pouzdana 'znanost' pomoću koje bismo mogli procijeniti relativnu smislenost ili besmislenost [oblika javnog ponašanja]“. Stackhouse $(1987,2)$ nadalje izražava svoje nezadovoljstvo: „Nemamo zajednički jezik za izražavanje teoloških tema u javnom prostoru, o tome što uključuje konačna stvarnost koja stoji iza ljudskog života u društvu“. Je li onda opravdano pitati se što bi bio "zajednički jezik" pomoću kojeg bismo mogli izgrađivati javnu teologiju s ciljem postizanja općeg dobra i dobrog života? Drugim riječima, na kojoj osnovi možemo formulirati javnu teologiju koja će uvažavati paradigmatske promjene u postmodernističkoj antropologiji?

\section{Religijska imaginacija i javna teologija}

Koncept imaginacije već se neko vrijeme koristi u konstruiranju javne teologije. Na primjer, Scott Holland služi se pojmom „religijske imaginarnosti“ kad govori o čovjekovu sudjelovanju u formiranju kulture, koja je odlučujuća i nezamjenjiva komponenta što omogućuje čovjekovo sudjelovanje te, samim time, i kulturno formiranje društva. Prema Hollandu (2005, 58-67), religijsko imaginarno je ona ljudska kreativna sposobnost - „polifonija kreativne kompleksnosti“ - koja omo-

2 Ovdje spominjemo neke suvremene javne teologe koji se i dalje drže logike modernističkoredukcionističke antropološke paradigme premda su u svojim djelima često svjesni paradigmatske promjene koju smo spominjali. Ovdje navodimo sljedeće pristupe: (1) uskogrudne pristupe (Max Stackhouse, Robert Benne, Edward Foley, Daniel Benga, Chris Green i George Hunsberger); (2) sociološke pristupe (Raymond Pland i Theologia Socialis); (3) retoričke pristupe (Linell Caddy); (4) tranzicijske pristupe koji uvažavaju promjene što su ih donijeli i globalizacija i postmodernizam (David Tracy i Duncan Forrester). 
gućuje „formiranje društvene vizije“ tako što objedinjuje tri elementa: teologiju, bogoštovlje i praksu.

Druga, raširenija upotreba koncepta imaginarnoga jest ona koju je predložio Charles Taylor $(2004,23)$, a to je „socijalna imaginacija“. Prema njegovu shvaćanju, socijalna imaginacija pretpostavlja „mnogo širi i dublji [okvir] nego intelektualna shema kojom se ljudi bave kad neaktivno razmišljaju o socijalnoj realnosti“. Taylor $(2004,23)$ nadalje ističe da se središnji aspekt na koji se poziva tiče „načina na koji ljudi zamišljaju svoje socijalno postojanje, načina na koji se uklapaju među druge, odvijanja interakcije između njih i njihove sredine, očekivanja koja se uglavnom ispunjavaju i dubljih normativnih koncepcija i predstava na kojima ova očekivanja počivaju“.

Kategorija socijalne imaginacije korisna je ponajviše iz tri razloga: (1) ona je uobičajeni način na koji ljudi izražavaju vlastitu imaginarnost pomoću predodžbi, narativa i legendi, (2) univerzalna je i dijeli je cjelokupni postojeći javni prostor, (3) predstavlja „uvriježeno shvaćanje koje omogućuje uvriježene prakse i općeprihvaćeni osjećaj legitimnosti“ (Taylor 2004, 23). Socijalna imaginacija se, stoga, odnosi na takvu mrežu senzibiliteta, predodžbi, narativa i prekognitivnih osjećaja koji funkcioniraju kao a priori spoznaja i iznimno su važni, kako za novu postmodernističku antropologiju tako i za analizu i konstrukciju suvremenog društva - stoga je ključna za konstrukciju suvremene javne teologije.

Moglo bi se još više pisati o drugim načinima uporabe kategorije imaginacije, no naš je cilj s jedne strane naglasiti koliko je za javnu teologiju važno shvatiti je ozbiljno, a s druge strane istaknuti značajan doprinos pojedinih rumunjskih istraživača u obogaćivanju shvaćanja navedene kategorije i otkriti kako se pravilno služiti njome u konstruiranju javne teologije. Ovdje želimo ukratko razmotriti doprinos rumunjskog povjesničara Luciana Boie, kao i doprinos Središta za istraživanje imaginarnoga (CRI) - „PHANTASMA“ pri sveučilištu Babeș-Bolyai University (UBB) iz Cluj-Napoce u Rumunjskoj.

U prvom dijelu svoje knjige „Prema povijesti imaginarnoga“ (u originalu: Pentru o istorie a imaginarului), Boia $(2007,7)$ govori o konceptu ,imaginarnoga“ kao ,jednom od najbezopasnijih načina za pristupanje dubinama ljudskog duha“. S pravom primjećuje da je definicija ovog koncepta problematična, često proturječna i uglavnom više zbunjuje nego što objašnjava njegovo značenje. Stoga, Boia $(2000,14)$ zaključuje da je „ono imaginarno samostalna stvarnost, koja posjeduje vlastiti ustroj i vlastitu dinamiku“. I, zato, držeći se Carla G. Junga, Boia predlaže ustroj arhetipa kao sastavnog elementa imaginarnoga te govori o osam arhetipskih ustroja koji sačinjavaju ono imaginarno: (1) svijest o transcendentnoj realnosti, (2) duša, smrt i život poslije smrti, (3) drugost ili alternost, (4) jedinstvo ili koherentnost, (5) aktualizacija podrijetla, (6) dešifriranje budućnosti, (7) „bijeg“, odnosno odbacivanje ljudskog stanja, (8) dijalektika suprotnosti. Kate- 
gorija imaginarnoga koja se obrazlaže u Boiainim tekstovima djeluje perspektivno i može se, oprezno, koristiti pri konstruiranju autentične suvremene javne teologije, odnosno one koja će ozbiljno shvaćati promjenu paradigme u novoj antropologiji, o čemu smo već govorili. ${ }^{3}$

Rumunjska škola već uživa važnu tradiciju istraživanja imaginarnoga putem CRI-a pri UBB-u, utemeljenom 2002. po inicijativi Corina Brage i drugih profesora s UBB-a, a koji je tijekom iste godine prihvaćen u mrežu Centers de Recherches sur l'Imaginaire, zajednice koja okuplja još 40 centara iz cijelog svijeta. Uz brojne druge studije, koje je CRI proveo, ovdje ćemo spomenuti noviju publikaciju iz pet tomova pod naslovom The Encyclopaedia of Romanian Imaginaries, što je opsežno istraživanje koje prati definirajuće komponente imaginarnoga u rumunjskoj literaturi, jeziku, religiji i umjetnosti. Treba obratiti pozornost na rad o religijskoj imaginaciji, što ga je koordinirao Ioan Chirilă, gdje se analizira rumunjska kršćanska religijska imaginacija, počev od kristijanizacije Dacije. Povrh svega, želimo istaknuti sveukupno uvodno proučavanje što ga potpisuje Ioan Chirilă, a koje oslikava konceptualne delimitacije kategorije „religijske imaginacije“, čime se još jednom ističe sve veći značaj koji danas pridajemo imaginarnome (Chirilă 2020, 13-27).

\section{Zaključak}

U ovom istraživanju nastojali smo pokazati da promjena paradigme u postmodernističkoj antropologiji nosi velike implikacije za način na koji definiramo sebe i za način na koji shvaćamo svoje kolektivno postojanje u društvu. Teolozi ne smiju zanemarivati ovu stvarnost ako želimo da poruka Evanđelja doprinese općem dobru i autentičnom procvatu čovjeka u suvremenom društvu. Vidjeli smo da se javna teologija, koja je proistekla iz potrebe za obnovom teološkog diskursa i iz reakcije na antropološku revoluciju, sada nalazi u razdoblju tranzicije u kojem nastoji otkriti metode pomoću kojih će moći obznaniti svoj glas u javnom prostoru s ciljem unaprjeđivanja društva. S obzirom na taj cilj, smatramo da je nuž-

3 Lucian Boia je dobro poznat po svojoj opsežnoj upotrebi kategorije imaginarnoga u konstruiranju povijesti. Objavio je brojna djela u Rumunjskoj i u Francuskoj, a mnoga su prevedena na engleski i njemački jezik. Njegova opsežna uporaba kategorije imaginarnoga omogućila mu je da se pozabavi raznim pitanjima, kao što su smak svijeta, komunizam, nacionalizam, demokracija itd. Nadalje, kategorija imaginarnoga pružila mu je karakteristično razumijevanje povijesti Rumunjske, a njegovi radovi o toj temi nailazili su na oštre kritike drugih rumunjskih povjesničara. Ovdje spominjemo nekoliko važnih istraživanja vezanih uz Boiainu uporabu kategorija imaginarnoga: For a History of the Imaginary (2000); History and Myth in Romanian Conscience (1997); The Scientific Mythology of Communism (1999); The End of the World: an endless history (1999); Between Angel and Beast: the myth of the different man from Antiquity to the present day (2004); Democracy's Myth (2003), itd. 
no hitno razumjeti kategoriju imaginarnoga i njegov doprinos obnovi teološkog diskursa. Na sreću, već postoje ozbiljna istraživanja u tom smjeru, koja će prije ili kasnije ostvariti velik utjecaj na naš današnji pristup teologiji.

\section{Literatura}

Benga, Daniel. 2007. „Misiunea internă a Bisericii“. INTER 1 (1-2): 113-22.

Benne, Robert. 1995. „The Paradoxical Vision: A Lutheran Nudge for Public Theology“. Pro Ecclesia 4 (2): 212-23.

Boia, Lucian. 2000. Pentru o istorie a imaginarului. Bukurešt: Humanitas.

Brooks, David. 2011. The Social Animal. New York: Random House.

Caddy, E. Linell. 1987. „A Model for Public Theology“. Harward Theological Review 80 (2): 193-212.

Chirilă, Ioan. 2020. Imaginar religios. Vol. 4. Bukurešt: Polirom.

Forrester, Duncan. 2004. „The Scope of Public Theology“. Studies in Christian Ethics 17 (2): 5-19.

Guinness, Os i David Wells. 2010. „Global Gospel, Global Era: Christian discipleship and mission in the age of globalization". Lauzanska konferencija u Cape Townu 23. listopada 2010. https://virtueonline.org/ cape-town-global-gospel-global-era (pristupljeno 13. svibnja 2020.).

Holland, Scott. 2005. „Public Theology and Democracy“. The Conrad Grebel Review 23 (5): 58-67.

Smith, James K. A. 2010. Thinking in Tongues: Pentecostal Contributions to Christian Philosophy. Grand Rapids: Eerdmans.

Stackhouse, Max. 1987. Public Theology and Political Economy: Christian Stewardship in Modern Society. Grand Rapids: Eerdmans. .2007. God and Globalization, Volume 4: Globalization and Grace. New York: Continuum.

Taylor, Charles. 2004. Modern Social Imaginaries. Durham: University Press.

Wilson, Timothy. 2002. Strangers to Ourselves: Discovering the Adaptive Unconscious. Cambridge (Massachusetts): The Belknap Press. 


\title{
Beneamin Mocan
}

\section{The Religious Imagination and Contemporary Public Theology}

\begin{abstract}
The process of secularization, known as the process of the privatization of religion or its denial from the public square, is a heritage of Modernity. This reality had (and continues to have) important consequences for Christian theology. Hence, the renewal of Christian theology is urgent, and has a lot at stake, especially regarding the need for a renewed Christian message within contemporary society. Though public theology appeared as a normal consequence of the need for the renewal of Christian theology, this renewal is not necessarily present in many of its methods. The rigidity of both of its theological methods and language remains a problem for public theology. This article suggests that the new shift in anthropology should be taken into consideration when constructing a viable public theology nowadays. The category of "religious imagination" is of utmost importance since it takes into consideration the new definition of the human being, which is in line more with postmodernism than modernity. Thus, the article sketches the possible substantial contribution the religious imagination brings towards the revitalization of contemporary public theology. Moreover, the article mentions recent Romanian studies on the imagination, which stresses, even more, the richness hidden within it and its possible usage for the construction of a viable public theology.
\end{abstract}

